An alternative form of explicit instruction would be to tell a subject that he will not be penalized in any way for guessing. Again the intelligent subject will be sure not to leave any item unanswered.

But what of the more common form of instruction that leaves the question of guessing vaguely undetermined? Here the subject has to construct a pay-off matrix for himself by divining what the probable scoring procedure is, and play his game accordingly. This form of instruction will favour the adventurous, even reckless, individual who enjoys risk-taking and believes in making the most of poorly structured situations. The more restrained, pedantic type of person will find himself at a disadvantage and will, almost inevitably, be penalized for his timidity. And this, it may be argued, is what life is like. The person who refuses to take unnecessary risks, no matter how favourable the pay-off function, is left behind in any race-for money, power, prestige or the more human satisfactions associated with the needs for companionship, warmth and affection. In a city, the person who waits until the street is entirely clear of traffic before crossing the road will certainly minimize the risk of being struck down by a vehicle, but he will cross very few roads.

So it would seem that most intelligence tests as presented are, in this matter of guessing, more like personality tests. Furthermore, a case can be made for the paradox that they are more effective as intelligence tests precisely because they do possess this characteristic of being a kind of personality test. This is not a new idea. It is expounded by Wechsler ${ }^{8}$ in his theory of non-intellective intelligence, and in which he attacks tho widespread assumption that personality and intellectual factors belong to different domains. Wechsler shows that there are personality components integral to mental functioning. In effect, he argues that the level at which an individual functions as an intelligent creature depends, among other things, on his emotional economy. The porson who behaves stupidly because of his emotional difficulties is still behaving stupidly. Whether or not he can overcome these difficulties and function at a higher level is a question comparable with that of the extent to which he can overcome an early environmental deficit of an intellectual kind.

This brings the argument back to the two questions with which we began. Wo can answer the second, more or less adequately, by saying that it is usually more intelligent to guess than pass over an item, but that everything will depend on the pay-off function. It would be simple enough to devise a pay-off function that would penalize subjects so heavily for wrong answers that it might pay to refuse to answer all the items. Existing tests do not, however, go to such extremes, and it is doubtful whether any intelligence test is made more effective as a discriminator by the use even of the standard correction for guessing. Indeed, there are grounds for arguing that test instructions should be more explicit about the penalties for guessing, so that the intelligent subject would be given an opportunity to derive the pay-off function and use his rational powers to overcome whatever personality factors might otherwise inhibit his performance. Without this information he is left in the invidious position of having both to allow for his own personality variables, and to divine the emotional attitude of the test constructor towards guessing.

${ }^{x}$ Hammerton, M., Brit. J. Educ. Psychol., 35, 249 (1965).

2 Shipley, W. C., J. Psychol., 9, 371 (1940).

3 Siegel, S., Nonparametric Statistics (McGraw-Hill, New York, 1956).

${ }_{4}^{4}$ Buros, O. K., The Fifth Mental Measurements Yearbook (Gryphon Press, New Jersey, 1959).

Swets, J. A., Tanner, W. P., and Birdsall, T. G., Psychol. Rev., 68, 301 (1961).

- Swets, J. A., Tanner, W. P., and Birdsall, T. G., Psychol. Rev., 68, 301 (1961) (Wiley, New York, 1956).

von Neumann, J., and Morgenstern, O., Theory of Games and Economic Behaviour (Princeton U.P., Princeton, 1947).

${ }^{*}$ Wechsler, D.,The Measurement and Appraisal of Adult Intelligence (Williams and Wilkins, Baltimore, 1958).

\title{
OBITUARIES
}

\section{Prof. L. R. Wager}

Prof. L. R. WAGER, professor of geology and Fellow of University College, Oxford, from 1950, died suddenly in London on November 20, 1965, at the age of sixty-one.

Lawrence Rickard Wager was born at Batloy, Yorkshire, on February 5, 1904, and educated at Leeds Grammar School. He proceeded to Pembroke College, Cambridge, where he graduated in 1926 with first-class honours in goology' in the Natural sciences Tripos. 'The award of a Goldsmiths' Company Studentship then enabled him to work at Cambridge for three years under Dr. Alfred Harker, chiefly on the mineralization and metasomatism of the Whin Sill.

This early interest in petrology was to continue for the rest of his life and to earn him a world-wide reputation as a leading authority on the petrogonesis, mineralogy and geochemistry of ignoous rocks. Wager was primarily a field geologist, however, in that he advocated and applied the principle that an interpretor of the Earth's history should soe the evidence for himself, and in this he was not tho sort of man to content himself with a limited objective. During his remarkable life he scaled the higher reaches of Everest, explored the Greenland Tcocap, mappod $35,000 \mathrm{~km}^{2}$ of rocks in one Arctic year, produced the most important account of an intrusive complex known in petrological literature, and established and directed, at Oxford, a particularly advanced geochemical research group dealing chiefly with radiometric age and isotope studies on rocks and minerals. The hallmark of a first-rate geologist is the ability to trace and find his evidence on any part of the Earth's surtace, to investigate the material using advanced laboratory techniques, and then to co-ordinate the minute details and translate them often in terms of the vastness of the Earth's framework and its time-span. Wager showed more than just the ability to do this, for he was out. standing in each field.

In 1929 he was appointed to a lectureship at the University of Reading, and the period between then and the outbreak of war saw him on several expeditions as both geologist and climber. At Cambridge he had been president of the Mountaineering Club, and in 1930 ho was choson by Gino Watkins to go to East Greenland as a member of his British Arctic Air Route Expedition. The three hazardous exploratory journeys in which Wager participated included a scientific reconnaissance of 200 miles of the treacherous Angmagssalik-Kangerdlugssuaq coast, a 250-mile return sledge journoy to relieve the inland Ice-cap weather station, and a 360 -mile return journey to climb the highest point then attained in the Arctic (Mount Forel). In 1932 he continued his geological reconnaissance investigations with the Scoresby Sound Committer's Second East Greenland Expedition, and went there again in 1934 with Dr. Charcot in the Pourquoi Pas? In 1935, with Augustine Courtauld and others of the British East Greenland Expedition, he climbed the highest mountains in the Arctic (the Watkins Mountains). With two Eskimo families he then wintered in the remote Kangerdlugssuaq region, together with his brother as botanist (Dr. H. G. Wager) and both their wives, and, in the company of W. A. Deer, he conducted a year's 
geological survey of about $35,000 \mathrm{~km}^{2}$ of Tertiary volcanic country (Southern Knud Rasmussens Land) and a remarkably detailed study of the associated plutonic complexes. He returned to the region in 1953 as joint leader of the East Greenland Geological Expedition, and at the time of his death had obtained financial support for a large-scale second geological expedition, which he was to have led jointly with Prof. W. A. Deer (Cambridge) in 1966 and 1967 .

Wager's skill on rock and ice was already well known when, in 1933, he joined Hugh Ruttledge's Everest expedition. On May 30 of that year, hampered by the beginning of frost-bite and with the oxygen supply from the air reduced to one third of normal, he and Wyn Harris reached 28,100 ft. in an assault on the summit. "Knowing these men as I do, they would not turn aside from a climb within the limits of the possible", wrote Ruttledge, but they were still capable of bringing back an ice-axe dropped by Mallory in 1924 and, in Wager's case, specimens from the limestone cliff that had barred their way to the summit. Wager wrote papers on the structural and geomorphological features of the Everest region, and on the fossilized organisms that lay in rocks uplifted nearly six miles above the seas in which they had once lived.

In 1939, after a number of papers by Wager on the Tortiary volcanic rocks of the region, he and W. A. Deer published a memoir on the petrology of the Skaergaard intrusion of East Greenland (Medd. om Gronland). Few treatises have had such an impact on the science of petrology, and even to-day it comprises one of the standard references on gabbroic layered intrusions. This large body of Tertiary igneous rock, exposed in the mountains and fjords of Kangerdlugssuaq, was shown by the authors to have formed by the slow cooling and crystal fractiona tion of about $500 \mathrm{~km}^{3}$ of basalt magma in a subsurface, funnel-shaped magma chamber. They proposed that as the crystals of a varied mineral assemblage formed, they were transported by magmatic convection currents to the floor of the chamber and deposited as successive layers. The near-perfect arrangement of the layers, exposed over about $7,500 \mathrm{ft}$. of thickness, provided the investigators with successive crops of minerals in equilibrium with the contemporary liquids over a relatively wide temperature range (starting at about $1,150^{\circ} \mathrm{C}$ ), and Wager and Deer provided a searching account of the textural, mineralogical and chemical variations, as well as a hypothesis, widely accepted to-day, on the mechanisms of formation of layered intrusions.

In 1944, Wager went to Durham as professor of geology after war service as an officer in the Royal Air Force. Ho had boen engaged on aerial photograph interpretation. advising troops on Arctic warfare, and sailing in Arctic seas with the Murmansk convoys, and was mentioned in despatches.

At Durham and, since 1950, at Oxford, he continued his profitable researches into the petrology of the Skaergatard intrusion. Joined by colleagues and a host of postgraduate students, the researches fell chiefly into three categories: mineralogical studies on tho silicate, oxide and sulphide minerals; geochomical studies on major and trace elements and on radioactive isotope ratios in the rocks and minerals; and calculations aimed at an understanding of the crystallization history of the intrusion. He was also cone $\rightarrow r n o d$ with investigations into the petrology of other layered intrusions in East Greenland and South Africa, of the Hebridean volcanic centres of Skye and Rhum, and of Recent volcanic centres in the West Indies. The results of his extensive work on layerod intrusions have formed the basis of a book almost completed at the time of his death, and due to be published this year (Wager and Brown, Layered Igneous Rocks). At Oxford, Wager was responsible for building up the facilities for petrographic, mineralogical and geochemical teaching and research which were to make it one of the better equipped centres in Britain. In addition, his period there saw an appreciable increase in the size of the whole department, including a new wing in 1964, and in the number of staff and students pursuing studies in most branches of geology.

Elected to a Fellowship of the Royal Society in 1946 , he was also a Fellow of the Geological Society of London (vice-president, 1951-53), of the Royal Geographical Society, and of the Mineralogical Society of America; a member of the Mineralogical Society (president, 1960-63); and one-time president of Section $\mathrm{C}$ of the British Association for the Advancement of Science (1958). He served on several university, national, and international committees, and was a founder editor of Geochimica et Cosmochimica Acta and Journal of Petrology. He was awarded the Arctic Medal (1933); the Mungo Park Medal (1936); the Lyell Fund (1935), the Bigsby Medal (1945), and the Lyell Medal (1962) of the Geological Society of London; and the Spendiarov Prize at the eighteenth International Geological Congress in 1948.

Wager was an inspiring toacher and a born leader, his integrity and seriousness of purpose instilling in all who worked with him a deep sense of loyalty. He set high standards and was unstinting in his appreciation of those who tried to meet them, for he had a liberal mind and a generous heart. Staff and students could always depend on his valuable advice and would find him ready to spend any spare time he might have on discussing their technical or personal problems, however trivial. He had a rather retiring personality, was reluctant to talk of his exploits, and rarely displayed his deeper emotions. Yet his authority, drawn from a splendid association of courage, intellect, and gentle modesty, could never fail to impress, even in a casual encounter.

He is survived by his widow, who groatly helped him in his work, two sons and three daughters.

G. Malcolm Brown

\section{Prof. W. F. Whittard}

Prof. Walter Frederick Whittard, professor of geology in the University of Bristol, died on March 2, at the age of 63 .

Born in Clapham, London, on October 26, 1902, Whittard was educated at Battersea County Secondary School; he was a founder member of the school Natural History Club, and an early interest in geology was estab. lished by the finding of fossils in the Chalk near Purley. After a brief spell at the Chelsea Polytechnic, he pro. ceeded to the Impcrial College of Science and Technology to read geology under W. W. Watts. There he also studied zoology, so that Whittard's subsequent major interests in stratigraphy and palaeontology especially were determined carly in his undergraduate days.

After obtaining his first degree, Whittard went to Shropshire at the instigation of Watts to study rocks of Llandovery age, and it was during this period that he developed a love for Shropshire and the Welsh Borderland which was to last the whole of his life. Following the award of the Ph.D. degree, Whittard went up to Sidney Sussex College, Cambridge. There he moved on to the study of Ordovician rocks, still in Shropshire, a critical area for a better understanding of the history of the Ordovician period.

In 1929, Whittard seized a chance opportunity to join the Cambridge East Greenland Expodition; he went as chief geologist, and carried out much useful work. This experience gave Whittard an enthusiasm for the Arctic regions which was later inherited by some of his students.

In 1931 he was appointed assistant lecturer in geology at the Imperial College of Science and Tochnology. As lecturer, Whittard remained there until 1937, when he was elected to the Chaning Wills chair of geology in the Univorsity of Bristol, lately vacated by Trueman. He 